\title{
PENERAPAN METODE COMPOSITE LOGIC UNTUK PERANCANGAN FRAMEWORK PENGUMPULAN BUKTI DIGITAL PADA MEDIA SOSIAL
}

\author{
Muhammad Na'im Al Jum'ah', Bambang Sugiantoro², Yudi Prayudi ${ }^{3}$ \\ 117917116@students.uii.ac.id, '2bambang.sugiantor@uin-suka.ac.id, ${ }^{1}$ prayudi@uii.ac.id \\ 1,3Universitas Islam Indonesia, ${ }^{2}$ Universitas Islam Sunan Kalijaga
}

\begin{abstract}
Abstrak
Media sosial telah menjadi kebutuhan utama dalam masyarakat. Namun sering kali media sosial dijadikan sebagai media untuk melakukan tindakan kejahatan. Dengan banyaknya tindak kejahatan yang memanfaatkan media sosial, maka perlu sebuah rancangan framework untuk mengumpulkan bukti digital di media sosial. Perancangan framework dilakukan dengan menggunakan metode Composite Logic. Composie Logic dapat digunakan untuk menentukan role model dari setiap variabel atau pola awal yang ingin dikolaborasikan. Composite Logic akan menghasilkan sebuah role model memiliki peran untuk menghasilkan pola sehingga dapat menghasilkan tujuan yang sama. Metode composite logic akan mengkolaborasikan framework Digital Forensics Investigation Models untuk menghasilkan Framework Pengumpulan Bukti Digital di Media Sosial. Berdasarkan data dan fakta yang ada, penelitian ini telah menghasilkan framework baru untuk Framework Pengumpulan Bukti Digital di Media Sosial. Framework ini memiliki empat tahapan utama dalam proses pengumpulan bukti digital di media sosial diantaranya tahapan Pre-process, Tahapan Collection, Tahapan Analysis dan Tahapan Report.
\end{abstract}

Kata kunci: Framework, Media Sosial, Bukti Digital, Composite Logic.

Social media has become a major part of society. But most of the time social media is used as a way people commit the crime. Due to numerous crimes that use social media, it is essential to design a framework to gather digital evidence on social media. This study develops the design of Framework by implementing Composite Logic Model. A logic Composite model can be used to determine the role model of any variable or pattern that need to collaborate. Composite Logic Model will produce a role model that has a role to produce patterns so that it can produce the same goal. A method of Composite Logic will collaborate with the Digital Forensics Investigation framework to produce a Digital Evidence Collection Framework on Social Media. Based on data and facts, this study has been producing a new framework of gathering digital evidence on social media. The framework has four main stages in the process of collecting digital evidence on social media including pre-process, collection, analysis, and report.

Keywords: Framework, Social Media, Digital Evidence, Composite Logic.

\section{Pendahuluan}

Media sosial kini semakin berkembang dan telah menjadi media untuk berkomunikasi bagi masyarakat. Banyaknya kemudahan mengakses media sosial dalam berbagai platform, memungkinkan seseorang dapat berinteraksi atau bertukar informasi serta gagasan dalam jejaring sosial [1]. Berdasarkan hasil survei, jumlah pengguna media sosial di dunia pada tahun 2018 mencapai 3,196 miliar, Sedangkan jumlah pengguna media sosial di Indonesia mencapai 130 juta pengguna ${ }^{1}$. Media sosial telah menjadi media yang populer untuk masyarakat, namun dengan popularitas media sosial saat ini banyak pengguna akun media sosial tanpa sadar telah menyebarkan informasi berupa data pribadi seperti alamat email, foto, nomor telepon, lokasi, tempat tinggal dan perilaku mereka setiap hari. Penyebaran informasi yang seperti ini akan memberi peluang bagi pelaku kejahatan untuk memanfaatkan informasi yang telah disebarkan tersebut. Berdasarkan data Bareskrim Polri sejak tahun 2015 tercatat ada 100 ribu akun di Media sosial yang menyebarkan hate speech $^{2}$. Beberapa pihak juga memanfaatkan media sosial untuk melakukan tindak kejahatan seperti seperti penipuan, cyber bullyng, perdagangan anak, prostitusi online, ujaran kebencian, sara dan lain

\footnotetext{
${ }^{1}$ https://wearesocial.com/blog/2019/01/digital-2019-global-internet-use-accelerates

https://kominfo.go.id/content/detail/13487/polri-indonesia-tertinggi-kedua-kejahatan-siber-didunia/0/sorotan_media
} 
ILKOM Jurnal Ilmiah Volume 11 Nomor 2 Agustus 2019 Terakreditasi peringkat 3 SK. No. 28/E/KPT/2019

sebagainya. Dalam penanganan kejahatan di media sosial, membutuhkan pengumpulan bukti digital yang akurat sehingga dapat menyelesaikan masalah-masalah kejahatan akibat penyalahgunaan media sosial. Pertumbuhan media sosial yang semakin meningkat, juga akan membantu penyidik dalam mengumpulkan bukti digital melalui media sosial.

Dalam forensika digital, bukti digital yang diperoleh dari media sosial akan sangat bermanfaat. Banyaknya informasi berupa data-data pribadi yang secara tidak sadar dipublikasikan di media sosial dapat digunakan penyidik sebagai barang bukti potensial untuk melacak kejahatan di media sosial. Data yang dipublikasikan tersebut dapat digunakan sebagai bukti langsung untuk menunjukkan keterlibatan seseorang dalam pelanggaran. Selain itu, data-data yang berada dalam ruang lingkup media sosial menawarkan informasi yang cukup banyak untuk mengetahui tentang motif dari setiap tindakan kejahatan yang dilakukan [2].

Informasi di media sosial yang berasal dari pengguna media sosial yang telah tersebar luas, sering kali tidak disadari oleh pengguna media sosial. Informasi-informasi berupa profil dari pengguna media sosial sangat mudah untuk diakses seperti jejaring sosial Twitter, Facebook, Instagram, Linkedin dan lain-lain. Dalam proses analisis media sosial melibatkan empat langkah berbeda yaitu penemuan data, pengumpulan, persiapan, dan analisis [3]. Selain itu data yang beredar di media sosial dapat dibagi menjadi empat kategori, yaitu pengguna, aktivitas, jaringan dan konten [2]. Jejak informasi digital di media sosial, jika dieksplorasi dengan benar, dapat memberikan informasi yang luar biasa dalam penyelidikan kriminal. Namun, mengeksplorasi media sosial untuk bukti potensial dan menghadirkan bukti-bukti ini di pengadilan bukanlah tugas yang mudah. Pencarian barang bukti dari media sosial memiliki tantangan karena perkembangan perangkat teknologi dan efektivitas forensik digital yang terus berkembang [4]. Bukti digital yang berasal dari media sosial harus dikumpulkan sesuai dengan aturan hukum yang berlaku serta ilmiah, sehingga tidak bertentangan dengan hak privasi individu. Tantangan yang muncul dalam pengumpulan bukti dari media sosial adalah autentikasi dari bukti digital yang telah dikumpulkan. Hal ini disebabkan karena banyaknya akun pengguna media sosial yang membuat profil palsu dan menyamar dengan nama orang lain. Selain itu, manipulasi data pengguna media sosial dengan memanfaatkan akun media sosial milik orang lain yang diperoleh secara ilegal menjadi masalah lain yang terjadi. Ada dua kriteria dasar yang harus dipenuhi agar diterimanya media sosial sebagai bukti. Pertama, perlu untuk membuktikan keaslian dari sumber barang bukti. Kedua, penting untuk menjamin keaslian dan integritas bukti yang disampaikan ke pengadilan [2].

Ada banyak cara mengumpulkan data untuk bukti digital dari media sosial. Salah satu caranya adalah dengan menerapkan metode Digital Forensic Intelligence + Open Source Intelligence (DFINT + OSINT). DFINT + OSINT memungkinkan untuk melakukan peninjauan dan pencarian informasi secara cepat dan tepat terhadap data yang cukup banyak di media sosial [5]. Selain itu metode lain yang dapat digunakan adalah dengan menerapkan Social Network Analysis (SNA) untuk memahami hubungan antara beberapa pengguna media sosial dalam berbagai tujuan seperti menyelesaikan kegiatan kriminal, mencegah serangan teroris, mengidentifikasi serangan sosial, mendeteksi penipuan, mengkategorikan dan mencocokkan akun jejaring sosial, dan lain-lain [6]. Metode data mining juga dapat digunakan untuk mengumpukan data dari media sosial. mengidentifikasi data komersial. Metode ini sangat efisien untuk analisis media sosial, akan tetapi tidak sesuai untuk tujuan hukum [7].

Menyadari pentingnya untuk mengatasi kejahatan di media sosial, maka perlu adanya sebuah panduan tentang tahapan-tahapan dan teknik investigasi media sosial untuk menghasilkan pembuktian secara ilmiah. Tahapan-tahapan ini akan dibuat dalam framework untuk mengumpulkan bukti digital pada media sosial. Telah banyak teknik untuk mengumpulkan data di media sosial, namun permasalahan yang muncul adalah dari banyak teknik yang ada, belum menerapkan sebuah standar untuk proses investigasi media sosial sesuai dengan aturan hukum yang berlaku sehingga dapat diterima dalam proses persidangan. Solusi yang akan di tawarkan pada penelitian ini adalah bagaimana merancang sebuah framework untuk mengumpulkan bukti digital di media sosial dengan menggunakan metode Composite Logic.

Composite Logic dapat digunakan untuk menentukan role model dari setiap variabel atau pola awal yang ingin dikolaborasikan. Composite Logic akan menghasilkan sebuh role model memiliki peran untuk menghasilkan pola sehingga dapat menghasilkan tujuan yang sama. Beberapa penelitian yang menggunakan Composite Logic untuk membangun sebuah framework diantaranya, penerapan metode Composite Logic untuk mengkolaborasikan framework terkait multimedia forensik. Pada penelitian tersebut beberapa framework seperti framework audio forensik, image forensik, dan video forensik di kolabarasikan dengan metode composite logic untuk menghasilkan framework multimedia 
ILKOM Jurnal Ilmiah Volume 11 Nomor 2 Agustus 2019 Terakreditasi peringkat 3 SK. No. 28/E/KPT/2019

forensik [8]. Selain itu, metode Composite Logic digunakan untuk membuat proses pemodelan terdistribusi. Penelitian ini mengembangkan perangkat lunak terdistribusi berbasis model dengan mengusulkan kegiatan split, edit, serta melakukan kolaborasi berdasarkan composite model sehingga menjadi mekanisme modularisasi suara formal yang memungkinkan untuk pemeriksaan konsistensi lokal dan transformasi sistematis [9].

\section{Metode}

\subsection{Media Sosial}

Media sosial berisi banyak sumber informasi dan bukti digital yang potensial untuk proses penyelidikan. Konten media sosial memberikan informasi yang sangat beragam untuk penyidik dalam proses investigasi kriminal jika dieksplorasi dengan tepat. Media sosial adalah sumber informasi yang cukup banyak untuk di ekplorasi tentang calon tersangka, korban, dan saksi seperti posting teks, daftar teman, gambar, data lokasi geografis, video, informasi demografis, dan sebagainya. Walaupun berkembang berbagai macam jenis platform media sosial, namun beberapa karakteristik umum akan tersedia bagi penyidik. Selain itu data-data yang ada di media sosial dapat dikategorikan menjadi empat kategori yaitu Pengguna, Aktivitas, Jaringan, dan Konten [2]. Data-data yang berada pada setiap platform media sosial dapat di akses melalui API yang telah disediakan oleh masing-masing platform media sosial.

\subsection{Digital Forensics Investigation Models}

Telah banyak penelitian yang dilakukan untuk model investigasi digital forensik. Model yang di kembangkan tersebut dilakukan untuk menjawab permasalahan kasus digital forensik. Pada kasus yang berhubungan dengan bukti digital di media sosial tentu akan membutuhkan motedologi untuk menyelesaikan masalah-masalah tersebut. Analisis forensik digital memerlukan bukti digital seperti analisis forensik fisik memiliki bukti fisik. Model investigasi forensik digital membuat bukti digital melalui berbagai fase dalam berbagai tahapan. Dalam proses penyelesaian kasus-kasus yang berhubungan dengan digital forensik dibutuhkan sebuah model investigasi sehingga bukti digital yang diperoleh dapat diterima dalam proses pengadilan. Menganalisis data sambil menjaga integritasnya merupakan hal penting karena integritas data sebagai bukti digital. Penegakan hukum dalam perlombaan abadi dengan penjahat dalam penerapan teknologi digital, dan membutuhkan pengembangan alat untuk secara sistematis mencari perangkat digital untuk bukti yang relevan [12].

\subsection{Logic Model}

Logic model dapat digunakan untuk identifikasi Timeframe yang akan di buat. Hal ini akan membantu dalam memperoleh hasil jangka pendek, menengah, dan jangka panjang serta membuat keputusan yang baik tentang sumber daya dan keputusan. Struktur logic model dapat digunakan untuk perencanaan program dengan menentukan parameter program dengan jelas. Banyak model logic yang ada, namun pada dasarnya semua mengandung konsep yang sama. Model logic akan bermanfaat untuk pemangku kepentingan untuk memperoleh masukan dalan kegiatan nya [13]

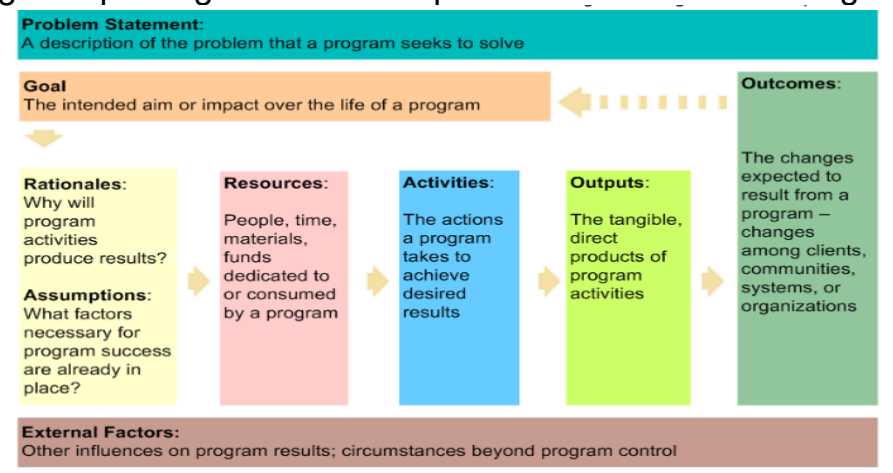

\subsection{Composite Logic}

Gambar 1. Template logic model

Logic model dapat digunakan untuk identifikasi Timeframe yang akan di buat. Hal ini akan membantu dalam memperoleh hasil jangka pendek, menengah, dan jangka panjang serta membuat keputusan yang baik tentang sumber daya dan keputusan. Struktur logic model dapat digunakan untuk perencanaan program dengan menentukan parameter program dengan jelas. Banyak model logic yang ada, namun pada dasarnya semua mengandung konsep yang sama. Model logic akan bermanfaat untuk pemangku kepentingan untuk memperoleh masukan dalam kegiatanya [13]. Composite Logic digunakan untuk mengkombinasikan beberapa struktur model menjadi sebuah 
ILKOM Jurnal Ilmiah Volume 11 Nomor 2 Agustus 2019 Terakreditasi peringkat 3 SK. No. 28/E/KPT/2019

model kesatuan yang tetap mempertahankan hirarki ataupun susunan awal kerangka model yang ada. Hal yang paling penting dalam Composite Logic model adalah menentukan role model dari setiap variabel ataupun pola awal yang ingin dikolaborasikan. Role model menjelaskan bagaimana beberapa objek berkolaborasi, satu ataupun dua peran yang bersamaan dalam sebuah pola untuk mencapai tujuan yang sama. Sebuah peran mewakili sudut pandang dari beberapa objek yang bekerjasama dengan berpegang pada sebuah tujuan. Pemodelan ini dapat membantu peneliti dalam mengeksplorasi keterhubungan dari aktivitas berbeda dengan tujuan yang sama. Sehingga memudahkan peneliti dalam melakukan klasifikasi dan kolaborasi beberapa framework yang pada akhirnya akan menghasilkan satu set framework [8]

Kelebihan lain dari composite adalah composite dapat meringkas realitas multi-dimensi yang kompleks dengan maksud untuk mendukung para pembuat keputusan dan lebih mudah diinterpretasikan untuk banyak indikator terpisah serta mengurangi ukuran yang terlihat dari serangkaian indikator tanpa menjatuhkan basis informasi yang mendasarinya. Dibalik beberapa kelebihan yang dimiliki composite, namun ada beberapa kekurangan antara lain dapat mengirim pesan kebijakan yang menyesatkan jika dibangun dengan buruk atau di salah artikan. Selain itu dapat mengundang kesimpulan kebijakan yang sederhana yang memiliki kemungkinan untuk di salah artikan, serta pemilihan indikator dan bobot bisa menjadi subyek perselisihan politik. [14].

\subsection{Metode Penelitian}

Metode penelitian yang dilakukan seperti pada gambar 2.

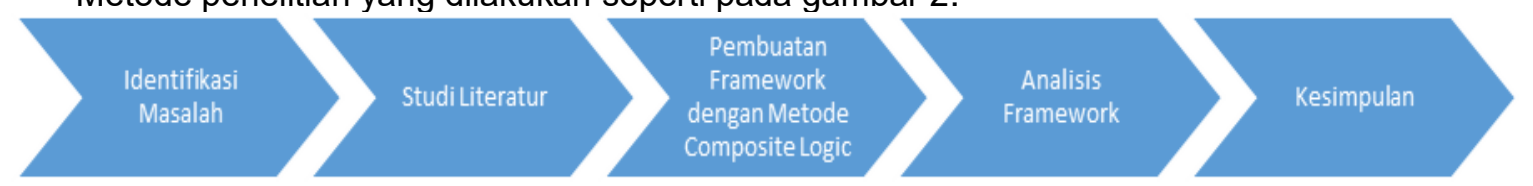

Gambar 2. Metode Penelitian

Pada penelitian ini tahapan awal yang dilakukan adalah dengan melakukan identifikai masalah untuk memperoleh dan menemukan topik penelitian yang akan diteliti lebih lanjut. Hal ini merupakan langkah awal yang dilakukan untuk memperoleh dan menentukan topik penelitian yang akan diteliti lebih lanjut. Tahapan selanjutnya adalah studi literatur untuk mengumpulkan bahan-bahan referensi yang terkait dengan penelitian, baik melalui buku, artikel, paper, jurnal, makalah, dan mengunjungi beberapa situs yang terdapat pada internet terkait dengan framework investigasi digital, pengumpulan data dari media sosial, metode Composite Logic Model serta analisis data sehingga dapat menunjukan tujuan akhir penelitian.

Tahapan selanjutnya adalah pembuatan framework dengan menggunakan metode Composite Logic. Pada tahapan ini akan menerapkan metode Composite Logic untuk membangun sebuah framework baru. Metode ini akan menggabungkan beberapa Digital Forensics Investigation Models sehingga dapat menghasilkan sebuah framework baru untuk melakukan pengumpulan bukti digital dari media sosial. Metode Composite Logic ini akan mengkombinasikan beberapa struktur model yang memiliki kesamaan menjadi sebuah model yang menyatu dengan tetap mempertahankan susunan awal dari kerangka model yang telah ada sebelumnya. Selain itu Composite Logic juga akan menentukan role model dari setiap variabel yang akan dikolaborasikan serta membantu dalam menenetukan keterhubungan dari variabel yang ada.

Tahapan selanjutnya adalah tahapan analisis framework. Tahapan ini merupakan proses evaluasi terhadap framework yang telah dirancang. Evaluasi terhadap framework digunakan untuk melihat kekurangan-kekurangan dalam tahapan-tahapan framework yang telah di rancang. Tahapan inilah yang akan menjadi penentu keberhasilan framework yang dirancang. Tahapan terakhir adalah tahapan pembuatan kesimpulan. Pada tahapan ini akan di jelaskan apakah framework yang di buat telah berhasil dilakukan.

\section{Hasil dan Pembahasan}

3.1. Identifikasi Digital Forensics Investigation Models (DFIM)

Ada empat jenis yang akan dijadikan kajian dalam penelitian ini diantaranya sebagai berikut:

- Digital Forensik Research Workshop (DFRWS) dikembangkan oleh [15] yang memiliki enam tahapan investigasi.

- Abstract Digital Forensics Model (ADFM) dikembangkan oleh [12] yang memiliki sembilan tahapan investigasi. 
ILKOM Jurnal Ilmiah Volume 11 Nomor 2 Agustus 2019

Terakreditasi peringkat 3 SK. No. 28/E/KPT/2019

- Computer Forensics Field Triage Process Model (CFFTPM) dikembangkan oleh [16] yang memiliki lima tahapan investigasi

- Digital Forensic Model Based On Malaysian Investigation Process (DFMMIP) dikembangkan oleh [17] yang memiliki tujuh tahapan investigasiA terkait :

Di bawah ini merupakan tabel hasil identifikasi Digital Forensics Investigation Models yang

\begin{tabular}{lllll}
\multicolumn{5}{c}{ Tabel 1. Hasil identifikasi DFIM terkait } \\
\hline No & $\begin{array}{l}\text { Digital } \\
\text { Forensics } \\
\text { Research } \\
\text { Workshop }\end{array}$ & $\begin{array}{l}\text { Abstract Digital } \\
\text { Forensics Model }\end{array}$ & $\begin{array}{l}\text { Computer Forensics } \\
\text { Field Triage Process } \\
\text { Model }\end{array}$ & $\begin{array}{l}\text { Digital Forensic Model } \\
\text { Based On Malaysian } \\
\text { Investigation Process }\end{array}$ \\
\hline 1 & Identification & Identification & Planning & Planning \\
2 & Preservation & Preparation & Triage & Identification \\
3 & Collection & Approach Strategy & User Usage Profile & Reconnaissance \\
4 & Examination & Preservation & Chronology Timeline & Transport \& Storage \\
5 & Analysis & Collection & Internet & Analysis \\
6 & Presentation & $\begin{array}{l}\text { Examination } \\
\text { Analysis }\end{array}$ & Case Specific & Proof \& Defense \\
7 & & Archive Storage \\
8 & & Presentation & & \\
9 & Returning Evidence & & A & \\
\hline
\end{tabular}

\subsection{Kolaborasi Digital Forensics Investiogation Models Terkait}

Setelah pada tahapan sebelumnya DFIM yang terkait dilakukan identifikasi, tahapan selanjutnya akan dikolaborasikan menjadi tahapan-tahapan yang selanjutnya akan digunakan untuk membangun framework pengumpulan bukti digital di media sosial. Proses kolaborasi ini dilakukan dengan menggunakan pemodelan logic, kesamaan terminology, dan Composite Role Model.
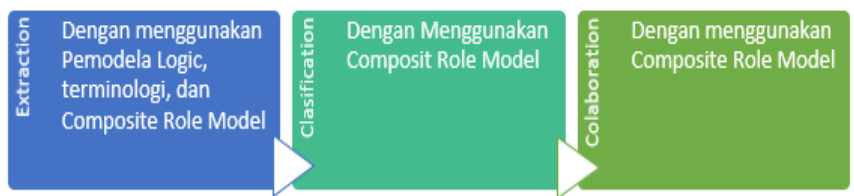

Gambar 3. Skema Penerapan Composite Logic

Tabel 2. Hasil Klasifikasi DFIM

\begin{tabular}{lllll}
\hline No. & Pre-process & \multicolumn{1}{c}{ Collection } & \multicolumn{1}{c}{ Analysis } & \multicolumn{1}{c}{ Report } \\
\hline 1 & Preparation & Identification & Analysis & Presentation \\
2 & Aproach Strategy & Preservation & Analysis & Presentation \\
3 & Planning & Collection & Chronology Timeline & $\begin{array}{l}\text { Returning Evidence } \\
\text { Archive Storage }\end{array}$ \\
5 & Internet & Examination & Case Specific & Analysis \\
6 & Planning & Identification & Anaf & \\
7 & & Perservation & Prof \& Defence & \\
8 & Collection & & \\
9 & Examination & & \\
10 & Triage & & \\
11 & User Usage Profile & & \\
12 & Identification & & \\
13 & Reconnaissance & & \\
\hline
\end{tabular}

: Tahapan dengan role model "Implies"

: Tahapan dengan role model "Prohibit"

: Tahapan dengan role model "Don't Care"

Tabel 3. Hasil Kolaborasi DFIM

$\begin{array}{lllll}\frac{N}{1} & \text { Pre-process } & \text { Collection } & \text { Analysis } & \text { Report } \\ & \text { Collection } & \text { Case Specific } & \text { Presentation }\end{array}$


ILKOM Jurnal Ilmiah Volume 11 Nomor 2 Agustus 2019

Terakreditasi peringkat 3 SK. No. 28/E/KPT/2019

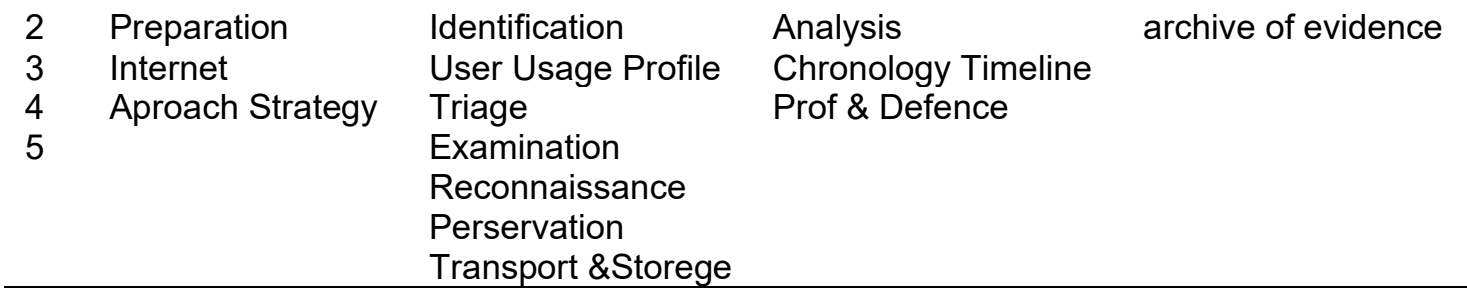

Dari hasil kolaborasi dengan menggunakan Composite Logic, maka dihasilkan sebuah framework hasil kolaborasi yang akan digunakan sebagai perancangan framework pengumpulan bukti digital di media sosial. Penyusunan framework ini mengikuti ketentuan sebagai berikut :

- Tahapan yang diidentifikasi pada output pada tabel klasifikasi DFIM akan di tetapkan sebagai tahapan utama dari framework karena telah diidentifikasi sebagai tahapan untuk tujuan dari kegiatan yang telah dideskripsikan dalam bentuk aktifitas.

- Tahapan hasil kolaborasi yang ditampilkan pada tabel 3 telah disusun secara berurutan dan memiliki hirarki yang sesuai karena pengaruh dari penerapan role model terhadap tahapan yang diperoleh dari proses identifikasi.

- Framework rancangan yang disusun ini akan dilakukan evaluasi yang bersumber dari penelitian sebelumnya.

Framework rancangan hasil kolaborasi dapat dilihat seperti pada tabel 3. dari hasil kolaborasi dari empat Digital Forensics Investigation Models (DFIM) yang ada terlihat bahwa jumlah tahapan yang ada menjadi lebih sedikit. Hal ini disebabkan karena tahapan-tahapan yang memiliki role model yang bersifat Implies telah dikolaborasikan karena memiliki nama dan terminologi yang sama pada tahapan tersebut.

Tabel 4. Tahapan framework awal

\begin{tabular}{|c|c|c|}
\hline No & $\begin{array}{l}\text { Tahapan Framework Hasil } \\
\text { Kolaborasi }\end{array}$ & ID \\
\hline \multicolumn{2}{|c|}{ Tahap Pre-process } & $\mathbf{P}$ \\
\hline 1 & Planning & P1 \\
\hline 2 & Preparation & P2 \\
\hline 3 & Internet & P3 \\
\hline 4 & Aproach Strategy & P4 \\
\hline \multicolumn{2}{|c|}{ Tahap Collection } & C \\
\hline 5 & Collection & C1 \\
\hline 6 & Identification & $\mathrm{C} 2$ \\
\hline 7 & User Usage Profile & C3 \\
\hline 8 & Triage & C4 \\
\hline 9 & Examination & C5 \\
\hline 10 & Reconnaissance & C6 \\
\hline 11 & Transport \& Storage & C7 \\
\hline 12 & Perservation & C8 \\
\hline \multicolumn{2}{|c|}{ Tahap Analysis } & A \\
\hline 13 & Case Specific & A1 \\
\hline 14 & Chronology Timeline & A2 \\
\hline 15 & Analysis & A3 \\
\hline 16 & Prof \& Defence & A4 \\
\hline \multicolumn{2}{|c|}{ Tahap Report } & $\mathbf{R}$ \\
\hline 17 & Presentation & R1 \\
\hline 18 & Archive Of Evidence & $\mathbf{R 2}$ \\
\hline
\end{tabular}

Untuk alur dalam framework hasil kolaborasi tersebut dapat dilihat pada gambar 4. Alur ini menjelaskan tahapan awal sampai tahapan akhir dalam tahapan framework hasil kolaborasi yang kemudian akan dijadikan sebagai framework untuk pengumpulan bukti digital di media sosial. 
ILKOM Jurnal Ilmiah Volume 11 Nomor 2 Agustus 2019 Terakreditasi peringkat 3 SK. No. 28/E/KPT/2019

\section{Kesimpulan dan Saran}

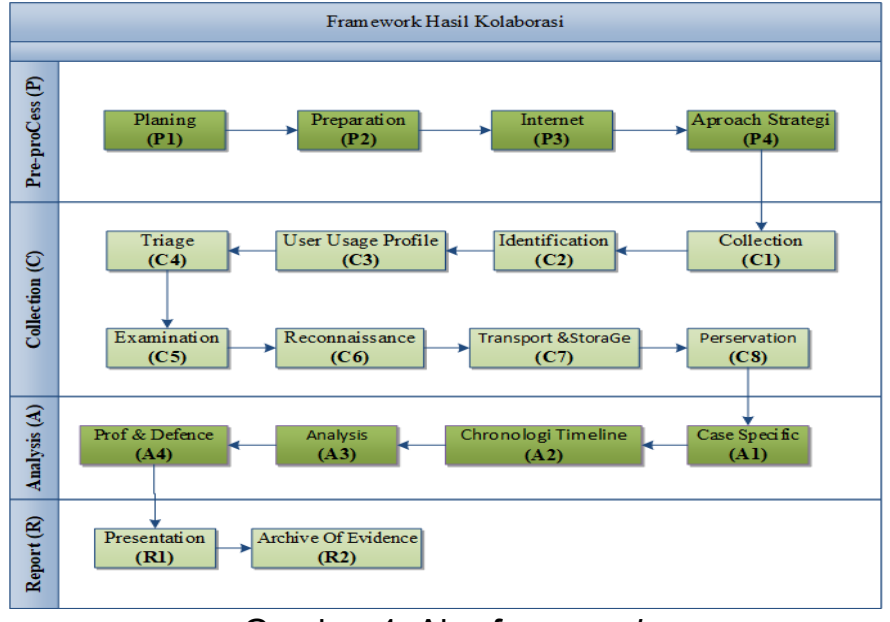

Gambar 4. Alur framework

Berdasarkan data dan fakta yang telah diperoleh dalam penelitian ini rancangan framework Pengumpulan Bukti Digital di Media Sosial ini dapat di gunakan untuk mengumpulkan bukti digital di media. Beberapa tahapan yang belum ada pada framework lain, kemudian dilengkapi pada framework ini. Perancangan framework ini dilakukan dengan menggunakan metode Composite Logic. Penerapan metode Composite Logic pada perancangan framework ini dilakukan dengan melakukan kolaborasi terhadap tahapan-tahapan yang terdapat pada empat framework Digital Forensics Investigation Models yaitu Digital Forensik Research Workshop (DFRWS) [15], Abstract Digital Forensics Model (ADFM) [12], Computer Forensics Field Triage Process Model (CFFTPM) [16], dan Digital Forensic Model Based On Malaysian Investigation Process (DFMMIP) [17]. Tahapan-tahapan pada empat Digital Forensics Investigation Models yang memiliki penamaan dan terminologi yang sama di kolaborasikan dan diberikan penamaan yang baru sesuai dengan kebutuhan framework ini. Perancangan framework ini menghasilkan beberapa tahapan yang belum ada pada tahapan lainya.

Beberapa penelitian sebelumnya telah mengembangkan berbagai jenis framework untuk kebutuhan investigasi dalam bidang digital forensik. Penelitian tersebut antara lain seperti framework untuk cloud computing [18][19], framework untuk memori forensik [20], framework investigasi smartphone [21], framework multimedia forensik [22], dan pengumpulan data yang bersifat open source intelligence [5]. Akan tetapi, berbagai pengembangan framework tersebut belum mencangkup dan memenuhi kebutuhan untuk investigasi forensik di media sosial. Hal ini disebabkan karena dalam proses investigasi di media sosial memiliki karakteristik tersendiri. Perbedaan karakteristik itulah yang menyebabkan sehingga framework ini dikembangkan untuk kebutuhan dalam proses digital forensik, serta untuk dapat memenuhi kebutuhan investigasi di media sosial dan dapat memenuhi aturan hukum yang berlaku.

Kelebihan dari Framework Pengumpulan Bukti Digital di Media Sosial adalah framework ini dapat di gunakan untuk proses pengumpulan data untuk dijadikan sebagai bukti digital di media sosial. Berbeda dengan penelitian-penelitian sebelumnya, proses awal sampai akhir pada framework ini telah memenuhi kebutuhan untuk pengumpulan bukti digital di media sosial. Akan tetapi data-data yang dapat dikumpulkan sebagai bukti digital pada framework ini, adalah data-data yang bersifat terbuka (Open Source) di internet.

\section{Daftar Pustaka}

[1] L. Sandor et al., "Social media in product development," 2018 Syst. Inf. Eng. Des. Symp. SIEDS 2018, vol. 40, pp. 88-93, 2018.

[2] H. Arshad, A. Jantan, and E. Omolara, "Evidence collection and forensics on social networks: Research challenges and directions," Digit. Investig., vol. 28, pp. 126-138, 2019.

[3] S. Stieglitz, M. Mirbabaie, B. Ross, and C. Neuberger, "Social media analytics - Challenges in topic discovery, data collection, and data preparation," Int. J. Inf. Manage., vol. 39, no. October 2017, pp. 156-168, 2018.

[4] S. L. Garfinkel, "Digital forensics research: The next 10 years," Digit. Investig., vol. 7, no. SUPPL., 2010.

[5] D. Quick and K. R. Choo, "Digital forensic intelligence : Data subsets and Open Source 
ILKOM Jurnal Ilmiah Volume 11 Nomor 2 Agustus 2019

Terakreditasi peringkat 3 SK. No. 28/E/KPT/2019

Intelligence ( DFINT + OSINT ): A timely and cohesive mix," Futur. Gener. Comput. Syst., vol. 78, pp. 558-567, 2018.

[6] M. Canbaz et al., "A Survey of Social Network Forensics," J. Digit. Forensics, Secur. Law, no. May 2017, 2017.

[7] B. Glavic, J. Siddique, P. Andritsos, and R. J. Miller, "Provenance for Data Mining," Proc. 5th USENIX Conf. Theory Pract. Proven., p. 5, 2013.

[8] N. Lizarti, B. Sugiantoro, and Y. Prayudi, "Penerapan Composite Logic Dalam Mengkolaborasikan Framework Terkait Multimedia Forensik," JISKA (Jurnal Inform. Sunan Kalijaga), vol. 2, no. 1, p. 26, 2018.

[9] D. Strüber, G. Taentzer, S. Jurack, and T. Schäfer, "Towards a distributed modeling process based on composite models," Lect. Notes Comput. Sci. (including Subser. Lect. Notes Artif. Intell. Lect. Notes Bioinformatics), vol. 7793 LNCS, pp. 6-20, 2013.

[10] M. Nuh Al-Azhar, "digital forensics," p. 302, 2012.

[11] K. Kent, S. Chevalier, T. Grance, and H. Dang, "Guide to integrating forensic techniques into incident response," 2006.

[12] M. R. Gregg Gunsch, Clint Carr, "An Examination of Digital Forensic Models," 4th Int. Work. Syst. Approaches to Digit. Forensic Eng. SADFE 2009, vol. 1, no. 3, pp. 42-53, 2009.

[13] P. F. Mccawley, "for Program Planning and Evaluation," no. September, 2015.

[14] M. Nardo, M. Saisana, A. Saltelli, and S. Tarantola, Handbook of Contructing Compsoite Indicators: Methodology and user guide. 2008.

[15] S. V. Korolev and S. I. Kuchanov, "A Road Map for Digital Forensic Research," Polym. Sci. U.S.S.R., vol. 24, no. 3, pp. 709-719, 1982.

[16] R. Mislan, J. Goldman, S. Debrota, M. Rogers, and T. Wedge, "Computer Forensics Field Triage Process Model," J. Digit. Forensics, Secur. Law, pp. 27-40, 2006.

[17] S. Perumal, "Digital Forensic Model Based On Malaysian Investigation Process," IJCSNS Int. J. Comput. Sci. Netw. Secur., vol. 9, no. 8, pp. 38-44, 2009.

[18] M. E. Alex and R. Kishore, "Forensics framework for cloud computing," Comput. Electr. Eng., vol. 60, pp. 193-205, 2017.

[19] G. Horsman, "Framework for Reliable Experimental Design (FRED): A research framework to ensure the dependable interpretation of digital data for digital forensics," Comput. Secur., vol. 73, pp. 294-306, 2018.

[20] A. Case, A. K. Das, S. J. Park, J. (Ram) Ramanujam, and G. G. Richard, "Gaslight: A comprehensive fuzzing architecture for memory forensics frameworks," Digit. Investig., vol. 22, pp. S86-S93, 2017.

[21] R. Ruuhwan, I. Riadi, and Y. Prayudi, "Penerapan Integrated Digital Forensic Investigation Framework v2 (IDFIF) pada Proses Investigasi Smartphone," J. Edukasi dan Penelit. Inform., vol. 2, no. 1, 2017.

[22] Y. D. Rahayu and Y. Prayudi, "Membangun Integrated Digital Forensics Investigation Framework (Idfif) Menggunakan Metode Sequential Logic," Semin. Nas. Teknol. Inf. dan Komun., no. March, pp. 2089-9813, 2014. 